\title{
High molecular weight glycoproteins released by expanding, pre-attachment sheep, pig and cow blastocysts in culture*
}

\author{
Rosalind A. Masters, R. M. Roberts, G. S. Lewis $\dagger$, W. W. Thatcher $\dagger$, \\ F. W. Bazer $\ddagger$ and J. D. Godkin
}

Department of Biochemistry and Molecular Biology, $\dagger$ Department of Dairy Science and $\ddagger$ Department of Animal Science, University of Florida, Gainesville, Florida 32610, U.S.A.

\begin{abstract}
Summary. Blastocysts isolated from sheep (Day 14-16), pigs (Day 16) and cows (Day 19) during the pre-attachment elongation phase were cultured for up to $30 \mathrm{~h}$ in a modified MEM medium in the presence of radioactive amino acids ( $\mathrm{L}-\left[{ }^{14} \mathrm{C}\right]$ leucine or $\mathrm{L}-\left[{ }^{35} \mathrm{~S}\right]$ methionine) to label protein and $\mathrm{D}-\left[{ }^{3} \mathrm{H}\right]$ glucosamine to label complex saccharides. All the blastocysts released considerable quantities of non-dialysable radioactive material into the medium at an approximately linear rate over the course of the incubation. Ion-exchange chromatography on DEAE cellulose at $\mathrm{pH} 8.2$ revealed that the major glucosamine-labelled product in the medium was a non-sulphated glycoprotein which eluted early in the salt gradient. None of the blastocysts produced any detectable glycosaminoglycan-like materials such as hyaluronic acid. The glycoprotein was purified by ion-exchange and gel filtration chromatography and had a molecular weight of $>660000$. Up to $100 \mu \mathrm{g}$ of this material could be isolated from incubations of 2 sheep conceptuses. It was relatively resistant to protease hydrolysis and consisted of approximately $50 \%$ carbohydrate and $50 \%$ protein. The main monosaccharide constituents, as revealed by gas-liquid chromatography, were galactose and $N$-acetylglucosamine plus some mannose and fucose. No sialic acid was present. The linkages between the carbohydrate chains and the peptide appeared to be resistant to alkaline borohydride cleavage and were probably, therefore, $N$-glycosidic.
\end{abstract}

\section{Introduction}

In the pig, sheep and cow implantation of the conceptus in the uterus is non-invasive and of the central or fusion type (see Steven, 1975). In these species the developing trophoblast does not erode the uterine epithelium, and attachment occurs fairly late (Days 16-20) by interdigitation of microvilli on the opposing surfaces of trophectodermal cells of the elongated blastocyst and underlying endometrial surface epithelium of the uterus. It is only after Day 20 of gestation that placentome formation begins in the sheep and cow (Boshier, 1969; King, Atkinson \& Robertson, 1980), while, in the pig, the uterine epithelium remains intact throughout pregnancy (Crombie, 1972; Friess, Sinowatz, Skolek-Winnisch \& Trautner, 1980; Perry, 1981). For this reason, the conceptuses of these animals are believed to rely upon endometrial glandular secretions for nutritional maintenance for a considerable portion of pregnancy (Bazer, Roberts, Sharp \& Thatcher, 1981). In

* Reprint requests to Dr R. M. Roberts, Department of Biochemistry and Molecular Biology, College of Medicine, University of Florida, Gainesville, FL 32610, U.S.A. 
addition, because of the superficial type of implantation and late attachment to the uterine wall, it is possible to flush intact conceptuses from the uterus of these animals until at least Days 20-25 of gestation. At around this stage the allantoic sac begins to inflate with fluid and hold the enlarged conceptus firmly within the uterine lumen. In experiments described here and elsewhere (Godkin, Bazer, Moffatt, Sessions \& Roberts, 1982), we have maintained elongating blastocysts in shortterm culture in attempts to isolate any secretory products. Our rationale was that proteins synthesized and secreted by the peri-implantation conceptus may be responsible for causing adjustments in maternal processes necessary for a successful pregnancy. Although there has been considerable speculation regarding possible immunosuppressive, gonadotrophic, antiluteolytic, mammotrophic and adherent properties of protein elaborated by the trophoblast (Klopper, 1980; Porter, 1980), such products have not been isolated from the early conceptuses of large domestic animals. The earliest products released by cultured sheep blastocysts are a low molecular weight acidic polypeptide and a high molecular weight glycoprotein (Godkin et al., 1982); the former is released for only a limited period (Days 13-21), i.e. during the critical time of pregnancy recognition. In this paper we have extended the study to pig and cow blastocysts as well.

\section{Materials and Methods}

\section{Animals and materials}

Materials. All materials employed, including tissue culture supplies, were supplied by the vendors noted by Godkin et al. (1982). L- $\left[{ }^{35} \mathrm{~S}\right] \mathrm{Methionine} \mathrm{(sp.} \mathrm{act.} 1270 \mathrm{Ci} / \mathrm{mmol}$ ), D-[6- $\left.{ }^{3} \mathrm{H}\right]$ glucosamine hydrochloride (sp. act. $4 \cdot 1 \mathrm{Ci} / \mathrm{mmol}$ ), L-[1-14 C]leucine (sp. act. $55 \mathrm{mCi} / \mathrm{mmol}$ ), L-[4,5- $\left.{ }^{3} \mathrm{H}\right] l \mathrm{leu}-$ cine (sp. act. $62 \mathrm{Ci} / \mathrm{mmol}$ ) and ${ }^{35} \mathrm{SO}_{4}$ were obtained from Amersham Corporation, Arlington Heights, Illinois.

Animals. Adult crossbred ewes, primarily of Rambouillet breeding, were mated as described previously (Godkin et al., 1982). Blastocysts were flushed from the uteri with sterile medium without hysterectomy (Moor \& Rowson, 1964; Godkin et al., 1982). Crossbred gilts, primarily of Duroc, Hampshire and Yorkshire breeding, were hysterectomized on Day 16 after mating as described previously (Bazer et al., 1975; Bazer, Sharp \& Roberts, 1978). Uteri were transferred to a sterile laminar flow hood and conceptuses were flushed from each uterine horn and collected in sterile culture dishes at $37^{\circ} \mathrm{C}$. Pregnant heifers (primarily of Angus breeding) were slaughtered on Day 19 after oestrus; the uterus was removed and conceptuses were flushed from the lumen as described for pigs.

In-vitro culture of conceptuses. A modified Eagle's minimum essential medium was prepared as described previously (Basha, Bazer \& Roberts, 1979; Godkin et al., 1982), but the L-leucine or Lmethionine content was reduced to one-tenth its normal level (depending upon which amino acid was being employed as tracer). Conceptuses were cultured in $15 \mathrm{ml}$ medium as described previously (Godkin et al., 1982) in an atmosphere of 50\% $\mathrm{O}_{2}-45 \% \mathrm{~N}_{2}-5 \% \mathrm{CO}_{2}$ (by vol.). Samples (0.5 ml) of medium were removed at intervals for estimating the release of macromolecular products. At the end of 24-30 h, incubations were terminated by chilling the mixture once and then centrifuging at $1200 \mathrm{~g}$ for $20 \mathrm{~min}$ to separate tissue and medium.

Processing of medium and chromatography. After incubation the remaining medium and samples taken during the culture period were dialysed against four changes of $10 \mathrm{mM}-\mathrm{Tris}-\mathrm{HCl}$ buffer $(\mathrm{pH}$ $8 \cdot 2$ ) over a $48 \mathrm{~h}$ period. Portions of these samples were estimated for radioactive content by liquid scintillation counting.

The remaining samples of medium were subjected directly to anion-exchange chromatography on DEAE-cellulose or to gel filtration on Sephacryl S-200. These procedures have been described in detail (Godkin et al., 1982). Protein that bound to a DEAE-cellulose column $(1.5 \times 10 \mathrm{~cm}$ ) was eluted with a linear salt gradient $(300 \mathrm{ml} ; 0-0.5 \mathrm{M}-\mathrm{NaCl})$ in $0.01 \mathrm{M}-\mathrm{Tris}-\mathrm{HCl}$ at $\mathrm{pH} 8.2$. Fractions 
(usually $5 \mathrm{ml}$ ) were collected and assayed for radioactivity. The $90 \times 1.5 \mathrm{~cm}$ column of Sephacryl S200 was equilibrated with $0.3 \mathrm{M}-\mathrm{NaCl}$ in $10 \mathrm{mM}$-Tris $-\mathrm{HCl}(\mathrm{pH} 8.2)$ and fractions of $3 \mathrm{ml}$ were collected. The protein standards were bovine serum albumin, ovalbumin, chymotrypsinogen and ribonuclease A.

The approximate size of the sheep and cow glycoproteins was measured on a column of Sepharose 6B $(90 \times 1.5 \mathrm{~cm})$ equilibrated with the same buffer as above. The standards were thyroglobulin (mol. wt of dimer $=660000$ ) and blue dextran. Fractions $(1 \cdot 7 \mathrm{ml})$ were collected.

Radiochemical procedures. Samples double labelled with ${ }^{3} \mathrm{H}$ and ${ }^{14} \mathrm{C}$ or ${ }^{3} \mathrm{H}$ and ${ }^{35} \mathrm{~S}$ were counted on a Beckman LS9000 scintillation counter equipped with a data reduction programme. Quenched ${ }^{14} \mathrm{C}$ and ${ }^{3} \mathrm{H}$ standards were purchased from Beckman Instruments, Palo Alto, California. Quenched standards for ${ }^{35} \mathrm{~S}$ were prepared freshly in the laboratory using small volumes of $\mathrm{CCl}_{4}$ $(2-20 \mu \mathrm{l})$ as the quenching agent. Procedures were otherwise as described by Basha et al. (1979).

Purification of the glycoprotein. The initial peak of radioactivity eluting from the DEAEcellulose column at $\sim 0-0.04 \mathrm{M}-\mathrm{NaCl}$ which contained most of the incorporated D-glucosamine label was collected, dialysed against distilled water and freeze-dried. It was redissolved in a small volume of Tris- $\mathrm{HCl}$ buffer and passed through the column of Sephacryl S-200. The radioactive peak eluting at the void volume of the column, which appeared to contain only a single component by Sepharose-6B chromatography, was assumed to represent pure glycoprotein.

Chemical analyses. Protein was determined by the method of Lowry, Rosebrough, Farr \& Randall (1951) using bovine serum albumin as the standard. Total neutral hexose was measured by the phenol sulphuric acid procedure (Dubois, Gilles, Hamilton, Riebers \& Smith, 1956), with galactose as a standard; amino sugars were determined by a modification of the Elson-Morgan procedure (Rondle \& Morgan, 1955), with D-glucosamine as standard; sialic acid was measured in two ways : by the alkali-Ehrlich method of Aminoff (1961) and by the thiobarbituric acid method of Warren (1959) with $N$-acetyl D-neuraminic acid as standard. Uronic acids were determined by the carbazole procedure (Bitter \& Muir, 1962), with D-glucuronic acid as the standard.

\section{Selective enzymic and chemical degradation procedures}

Pronase digestion. Approximately $25 \mu \mathrm{g}$ of double-labelled glycoprotein was placed in $1 \mathrm{ml} 0 \cdot 1 \mathrm{M}-$ sodium acetate, $\mathrm{pH} 6.0$ with $0.1 \mathrm{ml}$ of a $10 \mathrm{mg} / \mathrm{ml}$ solution of pronase (Sigma Protease Type XIV). After adding a drop of toluene to reduce bacterial contamination, the solution was incubated at $37^{\circ} \mathrm{C}$ for $48 \mathrm{~h}$ and then analysed by Sephacryl S-200 chromatography.

Neuraminidase digestion. An aliquant $(25 \mu \mathrm{l})$ of neuraminidase $(4 \mathrm{mg} / \mathrm{ml})$ was added to $\sim 25 \mu \mathrm{g}$ glycoprotein in $0.5 \mathrm{ml}$ phosphate buffer saline $\left(0.14 \mathrm{M}-\mathrm{NaCl}, 1.5 \mathrm{mM}-\mathrm{KH}_{2} \mathrm{PO}_{4}, 8 \mathrm{mM}-\mathrm{Na}_{2} \mathrm{HPO}_{4}, 3\right.$ $\mathrm{mm}-\mathrm{KCl}, 1 \mathrm{~mm}-\mathrm{CaCl}_{2}, 0 \cdot 5 \mathrm{mM}-\mathrm{MgCl}_{2}$ ) at $\mathrm{pH} \mathrm{7.4}$. The incubation was carried out at $37^{\circ} \mathrm{C}$ for $48 \mathrm{~h}$. The enzyme was obtained from Sigma (Clostridium perfringens type IX). Some samples were treated with alkali (Bertolini \& Pigman, 1967) before neuraminidase digestion to remove $O$-acetyl groups which render sialic acids resistant to neuraminidase attack.

Endo- $\beta$-galactosidase. A $10 \mu \mathrm{g}$ sample (a gift from Dr Y.-T. Li, Department of Biochemistry, Tulane University, New Orleans, U.S.A.) was incubated with $\sim 50 \mu \mathrm{g}$ pronase-generated glycopeptides (mol. wt $\sim 14000$ ) in $0.05 \mathrm{M}$-sodium acetate buffer, pH 6.0 at $37^{\circ} \mathrm{C}$ for $24 \mathrm{~h}$. Following incubation, the digest was passed through the Sephacryl S-200 column to separate the peptides from smaller oligosaccharides.

Alkaline borohydride treatment. A solution of sodium borohydride $(0 \cdot 1 \mathrm{M})$ was prepared in $0 \cdot 1 \mathrm{M}$ $\mathrm{NaOH}$. A $1 \mathrm{ml}$ aliquant of this was added to a dried sample of glycoprotein $(\sim 25 \mu \mathrm{g})$ and allowed to stand at $4^{\circ} \mathrm{C}$ for $48 \mathrm{~h}$. The solution was then neutralized using glacial acetic acid and dissolved gases were removed carefully under reduced pressure before chromatography on Sephacryl S-200.

\section{Procedure for preparation of trimethylsilyl-methylglycosides and GLC}

The glycoprotein was subjected to methanolysis and the resulting methylglycosides were analysed as their trimethylsilyl derivatives (Clamp, Bhatti \& Chambers, 1971). A sample of glycopro- 
tein (about $100 \mu \mathrm{g}$ ) was freed of salt by dialysis and a small amount of myo-inositol (usually $10 \mu \mathrm{g}$ ) added as an internal standard. The sample was then freeze-dried in a glass vial and suspended in 1 $\mathrm{ml}$ methanolic- $\mathrm{HCl}$ (absolute methanol containing $5 \%(\mathrm{w} / \mathrm{v}) \mathrm{HCl}$ ). The solution was sealed under $\mathrm{N}_{2}$ and heated in an oven at $95^{\circ} \mathrm{C}$ for $12 \mathrm{~h}$. The methanol and $\mathrm{HCl}$ were then removed under a stream of dry $\mathrm{N}_{2}$ and amino sugars were re-acetylated by the procedure of Kozulic, Ries \& Mildner (1979), using acetic anhydride with pyridine as catalyst. After removing these solvents, the methylglycosides were converted to their trimethylsilyl derivatives by treatment with $0.1 \mathrm{ml}$ anhydrous pyridine, $0.2 \mathrm{ml}$ hexamethyldisilazane and $0.1 \mathrm{ml}$ trimethylchlorosilane. The mixture was allowed to stand for $15 \mathrm{~min}$ and dried under $\mathrm{N}_{2}$. The derivatives were extracted in $0.1 \mathrm{ml} \mathrm{CCl}_{4}$ and samples (usually $10 \mu \mathrm{l}$ ) were used directly for gas-liquid chromatography (g.l.c.).

The instrument used was a Hewlett-Packard F \& M 402 gas chromatograph with dual flame ionization detectors. The carrier gas was nitrogen or helium at a flow rate of $60 \mathrm{ml} / \mathrm{min}$. The columns were standard $1.8 \mathrm{~m}$ tubes of internal diameter $3 \mathrm{~mm}$. Packing material was $3 \%(\mathrm{w} / \mathrm{w}) \mathrm{JXR}$ on 100-120-mesh Gas Chrom Q (Applied Science Labs, College Park, Pennsylvania). Separations were achieved under the following temperature conditions: $4 \mathrm{~min}$ isothermal hold at $140^{\circ} \mathrm{C}$, followed by a $2^{\circ} \mathrm{C} / \mathrm{min}$ increase to $235^{\circ} \mathrm{C}$. The initial temperature of the flash heater was $195^{\circ} \mathrm{C}$ and that of the detector $215^{\circ} \mathrm{C}$. The relative response factor for each sugar was calculated in relation to an internal standard of myo-inositol. These molar responses were as follows (for 5 determinations \pm s.d.): L-fucose $=0.326 \pm 0.026 ;$ D-mannose $=0.505 \pm 0.014 ;$ D-galactose $=0.456 \pm 0.011 ; N$ acetyl D-glucosamine $=0.556 \pm 0.026 ; N$-acetyl D-galactosamine $=0.547 \pm 0.023 ; N$-acetyl Dneuraminic acid $=0 \cdot 330 \pm 0 \cdot 048$. The above monosaccharides were obtained from Sigma and used without purification.

\section{Results}

Release of extracellular product. Conceptuses were cultured for up to $32 \mathrm{~h}$ in medium containing L[ ${ }^{35}$ S $]$ methionine $(100 \mu \mathrm{Ci})$ or $\mathrm{L}-\left[1-{ }^{14} \mathrm{C}\right]$ leucine $(50 \mu \mathrm{Ci})$ and $\mathrm{D}-\left[1-{ }^{-3} \mathrm{H}\right]$ glucosamine $(100 \mu \mathrm{Ci})$. Duplicate aliquots $(0.5 \mathrm{ml})$ of medium were removed at various times, and low molecular weight materials were removed by dialysis. The radiolabelled non-diffusible material remaining was then counted (Text-fig. 1).

All the conceptuses released material, which was not dialysable, into the incubation medium throughout the incubation period. This suggests that the tissues remained viable for at least $24 \mathrm{~h}$ and continued to produce and secrete protein and complex carbohydrate. The results in Text-fig. 1 are based upon experiments with $\mathrm{L}-\left[{ }^{35} \mathrm{~S}\right]$ methionine rather than $\mathrm{L}-\left[{ }^{14} \mathrm{C}\right]$ leucine, but essentially similar results were obtained with leucine. With all precursors, there was some suggestion of a slight lag during the first $0-4 \mathrm{~h}$ of incubation which would be expected if the materials released into the medium were secretory products.

Considerable variation was found in the production of extracellular product by individual conceptuses. However, the trends were always very similar, namely a slight lag followed by a more or less linear production of dual-labelled material for up to $24 \mathbf{h}$.

\section{Ion-exchange chromatography of dialysed medium}

The dialysed medium from the end of the incubation period was subjected to ion-exchange chromatography on DEAE-cellulose at $\mathrm{pH} 8.2$ after removing positively charged components by passing the medium through a small column of CM-cellulose. The elution patterns on DEAEcellulose were complex and distinctive for tissue from each species (Text-fig. 2). However, in each species, most of the D-glucosamine-derived label eluted as a narrow peak very early in the salt gradient. This peak was sharper for pig than in cow and sheep blastocysts, but in all 3 species the 


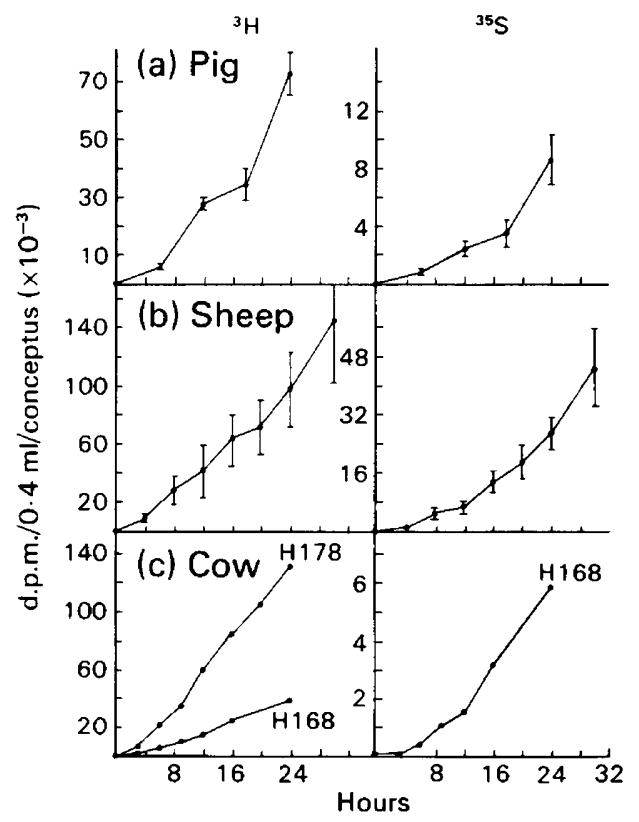

Text-fig. 1. Release of ${ }^{3} \mathrm{H}$ - and ${ }^{35} \mathrm{~S}$-labelled macromolecular components by (a) Day-16 pig, (b) Day-16 sheep and (c) Day-19 cow conceptuses over a 24- or 30-h period. Sheep conceptuses were incubated in $15 \mathrm{ml}$ medium containing $100 \mu \mathrm{Ci} \mathrm{L}-\left[{ }^{35} S\right]$ methionine and $100 \mu \mathrm{Ci} \mathrm{D}-\left[{ }^{3} \mathrm{H}\right] \mathrm{glu}-$ cosamine. Because of entanglement of the threads, the entire flush from one uterine horn of a pig was assumed to represent 5 conceptuses. Samples of medium $(0.4 \mathrm{ml})$ were withdrawn at 4-h intervals and dialysed against $0.01 \mathrm{M}-\mathrm{Tris}-\mathrm{HCl}(\mathrm{pH} \mathrm{8.2)}$ ) as described in 'Materials and Methods'. Results are means \pm s.e.m. for 4 (pig) and 6 (sheep) experiments. Only 2 experiments of this kind were carried out with cow blastocysts from 2 heifers.

major ${ }^{3} \mathrm{H}$-containing fraction (i.e. labelled with glucosamine) was eluted in fractions $30-35(\sim 0.04$ $\mathrm{M}-\mathrm{NaCl}$ ).

The column was then washed with $0.5 \mathrm{M}-\mathrm{NaCl}$ and $1.5 \mathrm{M}-\mathrm{NaCl}$ : neither of these treatments eluted significant amounts of radioactivity, suggesting that the conceptus does not release the sulphated proteoglycans that elute at such high concentrations of salt from DEAE-cellulose (Welch \& Roberts, 1975).

It was also evident that the ${ }^{3} \mathrm{H}$-labelled peak incorporated little ${ }^{35} \mathrm{~S}$ from L-methionine. However, if $\mathrm{L}-\left[{ }^{14} \mathrm{C}\right]$ leucine was employed as a precursor of protein, the material from fractions $30-35$ as well as that in peaks eluting later, was strongly labelled (see Text-fig. 3), suggesting that the material contained significant amounts of leucine, but not methionine.

The material in fractions 30-35 was combined for further analysis. The remainder of the results reported in this paper deal primarily with material derived from sheep. However, except where specifically stated, similar results were obtained with cow and pig blastocysts.

\section{Gel filtration}

When whole medium from $L_{-}\left[{ }^{3} \mathrm{H}\right]$ leucine incubations was run directly on a column of Sephacryl S-200 without prior fractionation using DEAE-cellulose, blastocysts from all 3 species gave rise to a major peak of labelled protein eluting at the void volume (Text-fig. 4), again suggesting that all 3 species released a similar product of high molecular weight. When the early eluting material from the DEAE-cellulose column (0.04 M salt; fractions 30-35) was subjected to Sephacryl S-200 gel 


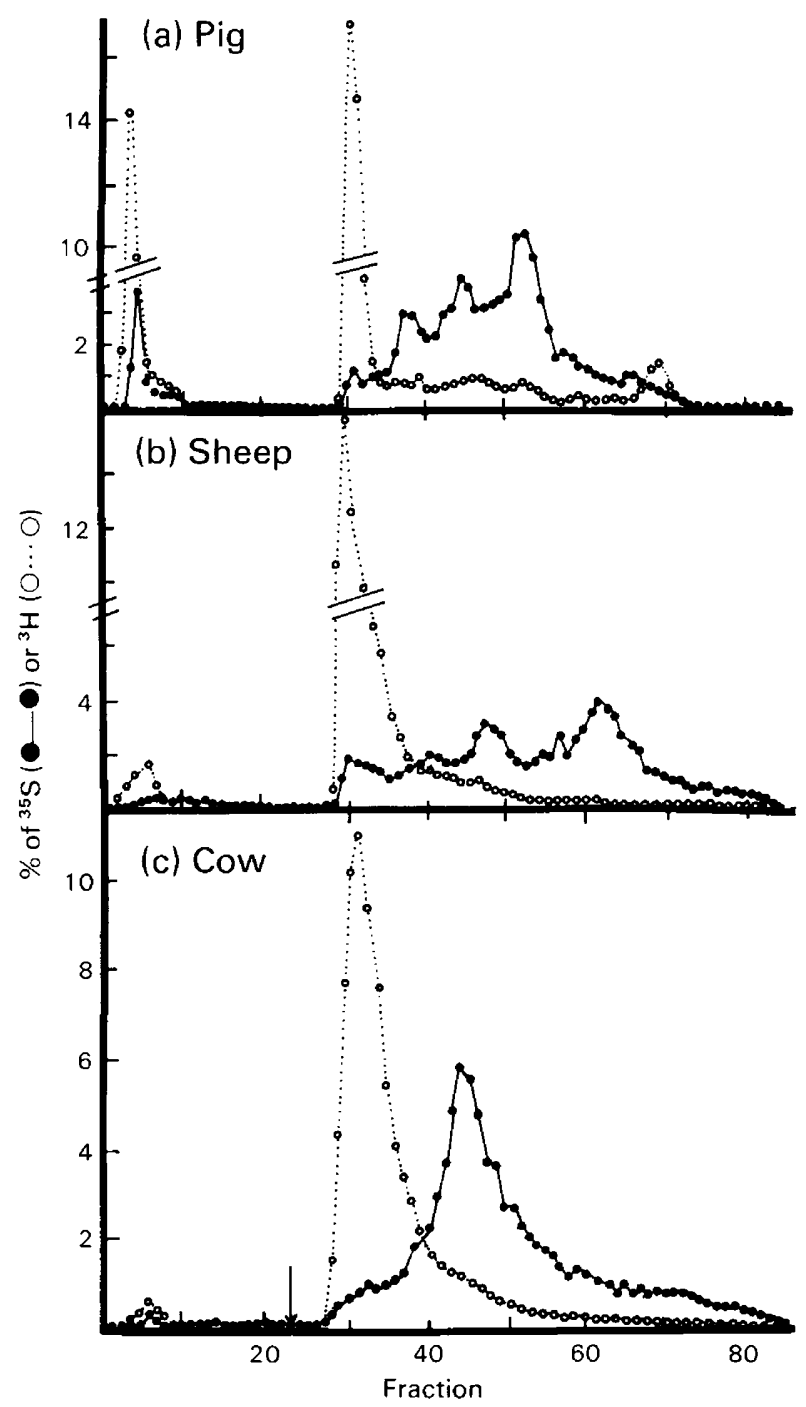

Text-fig. 2. DEAE-ion exchange chromatography of dialysed medium following a 24-h incubation of (a) pig, (b) sheep or (c) cow conceptuses in $\mathrm{L}_{-}\left[{ }^{35} \mathrm{~S}\right]$ methionine $(100 \mu \mathrm{Ci})$ and $\mathrm{L}-\left[{ }^{3} \mathrm{H}\right] \mathrm{gluco}-$ samine. The arrow indicates the start of the $0-0.5 \mathrm{M}-\mathrm{NaCl}$ gradient. Samples $(0.1 \mathrm{ml})$ were removed from each fraction $(4 \mathrm{ml})$ and analysed for ${ }^{35} \mathrm{~S}$ or ${ }^{3} \mathrm{H}$ content. To normalize the 2 curves, results are presented as percentage ${ }^{35} \mathrm{~S}$ or ${ }^{3} \mathrm{H}$ recovered. Total radioactivity (d.p.m.) applied was: pig, $2.62 \times 10^{6}{ }^{3} \mathrm{H}, 0.35 \times 10^{6}{ }^{35} \mathrm{~S}$; sheep, $5.25 \times 10^{6}{ }^{3} \mathrm{H}, 1.8 \times 10^{6}{ }^{14} \mathrm{C}$; cow, $1.50 \times 10^{6}{ }^{3} \mathrm{H}, 0.23 \times 10^{6}{ }^{14} \mathrm{C}$. Only the first 60 fractions of the gradient are shown since they contained all of the radioactivity.

filtration most of the radioactivity eluted at the void volume of the column (see Text-fig. 5a). Further chromatography of the void volume peak on a column of Sepharose-6B showed that the material eluted as a fairly symmetrical but broad peak, ahead of the thyroglobulin dimer, but behind blue dextran (Text-fig. 5b). The average molecular weight of the material was therefore slightly greater than 660000 . The breadth of the peak may indicate some heterodispersity which is not unusual among glycoproteins. We conclude that the major glucosamine-labelled product re- 


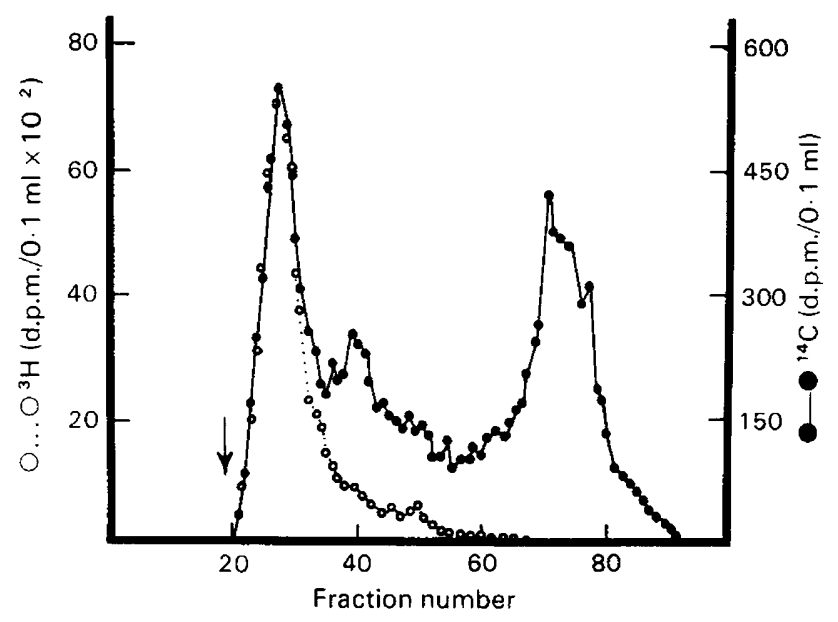

Text-fig. 3. DEAE-ion-exchange chromatography of dialysed medium following a 24-h incubation of a sheep conceptus (Day 16$)$ in $\mathrm{L}-\left[{ }^{14} \mathrm{C}\right]$ leucine $(50 \mu \mathrm{Ci})$ and $\mathrm{D}-\left[1-^{3} \mathrm{H}\right]$ glucosamine $(100$ $\mu \mathrm{Ci})$. The arrow indicates the start of the gradient. Samples $(0.1 \mathrm{ml})$ were removed from each fraction $(5 \mathrm{ml})$ and analysed for ${ }^{14} \mathrm{C}$ or ${ }^{3} \mathrm{H}$.

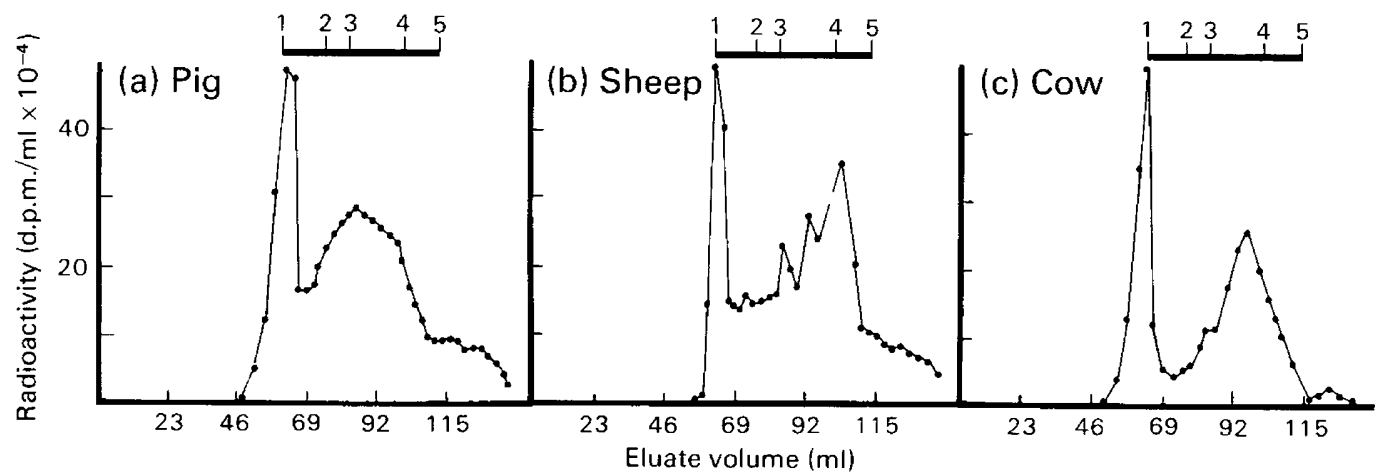

Text-fig. 4. Sephacryl S-200 gel chromatography of a portion of dialysed but unfractionated medium following incubation of (a) Day-16 pig, (b) Day-14 sheep or (c) Day-16 cow conceptuses for $24 \mathrm{~h}$ in medium containing $\mathrm{L}-\left[{ }^{3} \mathrm{H}\right]$ leucine $(100 \mu \mathrm{Ci})$. The column $(90 \times 1.5 \mathrm{~cm})$ was eluted with $0.01 \mathrm{M}$-Tris- $\mathrm{HCl}(\mathrm{pH} \mathrm{8.2)}$ containing $0.3 \mathrm{M}-\mathrm{NaCl}$. Elution positions of the standards, 1 (blue dextran), 2 (bovine serum albumin), 3 (albumin), 4 (chymotrypsinogen) and 5 (ribonuclease) are shown.

leased by the conceptuses is a glycoprotein of high molecular weight. Pretreatment with $0 \cdot 1 \mathrm{M}$ mercaptoethanol did not reduce the size of the glycoprotein.

In a separate experiment the glycoprotein was concentrated and approximately $10^{5} \mathrm{~d} . \mathrm{p} . \mathrm{m}$. were subjected to electrophoresis in $10 \%$ polyacrylamide slab gels in the presence of SDS. After drying the gels, the glycoprotein was detected by fluorography (results not shown; see Godkin et al., 1982). Although the glycoprotein migrated into the stacking gel, it failed to enter the second dimension resolving gel. The glycoprotein therefore retained its high molecular weight characteristics, even in the presence of SDS and after denaturation by boiling in SDS and mercaptoethanol.

When ${ }^{35}$ S-labelled material from the DEAE-cellulose column was concentrated and subjected 


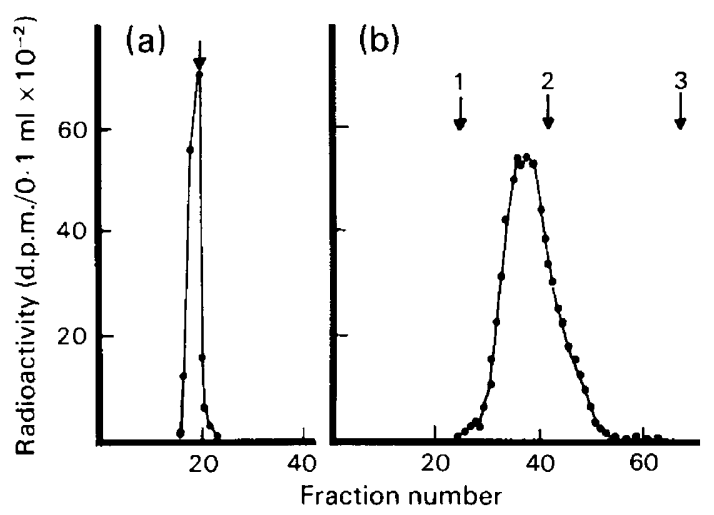

Text-fig. 5(a). Sephacryl S-200 gel chromatography of the initial glucosamine-labelled peak obtained by DEAE-cellulose chromatography of the medium after incubating a Day-16 sheep conceptus in presence of $D-\left[{ }^{3} \mathrm{H}\right]$ glucosamine and $L-\left[{ }^{14} \mathrm{C}\right]$ leucine. Fractions $(28-38)$ from a $\mathrm{DEAE}$-cellulose ion exchange run (approximate peak elution position $0.05 \mathrm{M}-\mathrm{NaCl}$ ) were concentrated and loaded onto the Sephacryl S-200 column $(90 \times 1.5 \mathrm{~cm})$. Fractions $(3 \mathrm{ml})$ were collected and assayed for ${ }^{3} \mathrm{H}$ and ${ }^{14} \mathrm{C}$. Only the ${ }^{3} \mathrm{H}$ values are shown because the patterns for the two isotopes was identical. The void volume is indicated by the arrow. (b) Sepharose CL-6B gel chromatography of the D-glucosamine-labelled material eluting at the void volume after gel chromatography on Sephacryl S-200. The $90 \times 1.5 \mathrm{~cm}$ column of Sepharose CL-6B was equilibrated with $0.01 \mathrm{M}$-Tris- $\mathrm{HCl}(\mathrm{pH} \mathrm{8.2)}$ containing $0.3 \mathrm{M}-\mathrm{NaCl}$ and $1.7 \mathrm{ml}$ fractions were collected. Although doubly labelled, only ${ }^{3} \mathrm{H} \mathrm{d.p.m.} \mathrm{are} \mathrm{shown} \mathrm{because} \mathrm{the} \mathrm{patterns} \mathrm{for} \mathrm{the} \mathrm{two}$ isotopes were almost identical. Arrows indicate the elution positions of blue dextran (1), thyroglobulin dimer (2) and sucrose (3).

to gel filtration on Sephacryl S-200 or Sepharose-6B, the remaining traces of ${ }^{35}$ S were separated from the glycoprotein. We conclude that the glycoprotein probably does not contain L-methionine as one of its constituent amino acids.

\section{Selective degradation of the glycoprotein}

Pronase digestion. When a sample of glycoprotein purified by Sephacryl S-200 gel chromatography was treated with pronase and rechromatographed on the same Sephacryl column, ${ }^{3} \mathbf{H}$ and ${ }^{14} \mathrm{C}$ radioactivity appeared at the void volume of the column, but the major double-labelled peak was broad, with a pronounced trailing edge (Text-fig. $6 \mathrm{a}$ ). In addition, about $50 \%$ of the ${ }^{14} \mathrm{C}$ (from $\mathrm{L}$-leucine) eluted in the region of the salt volume. However, no ${ }^{3} \mathrm{H}$ (from $\mathrm{D}$-glucosamine) appeared in these low molecular weight compounds. We conclude that only a portion of the glycoprotein is readily susceptible to proteolysis.

Neuraminidase digestion. Digestion with neuraminidase was expected to release a significant portion of any sialic acid present in the glycoprotein. This monosaccharide, which would be labelled with ${ }^{3} \mathrm{H}$ from glucosamine (Kohn, Winzler \& Hoffmann, 1962; Davidson, 1965), would then elute at the salt volume. However, neuraminidase digestion failed to release low molecular weight products (results not shown).

Alkaline borohydride treatment. Alkaline borohydride treatment cleaves the $O$-glycosidic linkage between $N$-acetyl-D-galactosamine and threonine and/or serine on glycoproteins, and is frequently used to diagnose the presence of mucin-like or $O$-linked chains (Spiro, 1972; Zinn, Plantner $\&$ Carlson, 1977). When the products of alkaline borohydride treatment of the sheep glycoprotein were chromatographed on the Sephacryl S-200 column, the main concentration of ${ }^{3} \mathrm{H}$ and ${ }^{14} \mathrm{C}$ was 


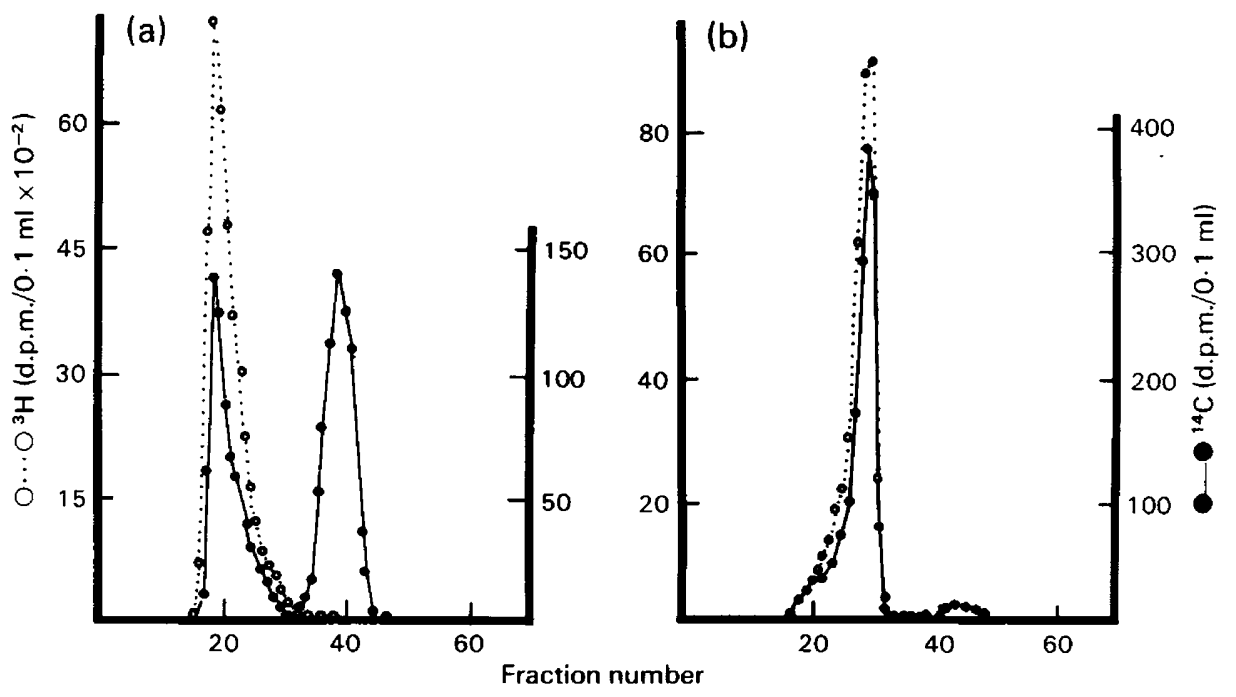

Text-fig. 6. Sephacryl S-200 chromatography of double-labelled sheep glycoprotein following (a) digestion with pronase and (b) treatment with alkaline borohydride. The glycoprotein was purified from an incubation in which a Day-16 sheep conceptus had been cultured in the presence of $\mathrm{D}-\left[{ }^{3} \mathrm{H}\right] \mathrm{glucosamine}$ and $\mathrm{L}-\left[{ }^{14} \mathrm{C}\right]$ leucine.

shifted from the void volume region (fraction 18) to a broad peak centred around fraction 30 with an apparent molecular weight of about 14000 (Text-fig. 6b). This peak was asymmetrical with radioactivity detectable on the leading edge from fraction 20 onwards. A small amount of ${ }^{14} \mathrm{C}$ (about $10 \%$ of the total) appeared in the salt volume, but no ${ }^{3} \mathrm{H}$ was detectable in the low molecular weight compounds. With the pig and cow material, cleavage by alkaline borohydride gave rise to rather larger fragments (mol. wt $\simeq 25000$ ).

Although the alkaline borohydride treatment cleaved the glycoprotein into smaller fragments, it did not lead to a separation of the majority of the carbohydrate label from that of polypeptide material.

\section{Protein and carbohydrate content of the sheep glycoprotein}

Purified glycoprotein was analysed for hexose, amino sugar, and protein. Results from a pool of material derived from two conceptus incubations (Exp. 1: Ewes 133 and 150) gave a total recovery of $100 \mu \mathrm{g}$ protein $(48 \%), 56 \mu \mathrm{g}$ hexose $(27 \%)$ and $51 \mu \mathrm{g}$ amino sugar $(25 \%)$. In a second experiment (Ewes 40 and 141) $78 \mu \mathrm{g}$ protein and $40 \mu \mathrm{g}$ amino sugar were recovered, but insufficient material was present to allow the hexose to be measured.

Attempts to determine sialic acid and uronic acid on 2 separate samples were unsuccessful. Two different procedures for sialic acid determination were employed; both were negative. The results thus suggested that the glycoprotein lacked sialic acid and was approximately $50 \%$ by weight carbohydrate. Of this carbohydrate, about one-half was hexose and one-half amino sugar.

\section{Gas-liquid chromatography}

Gas-liquid chromatography revealed the presence of $\mathrm{L}$-fucose, D-mannose, D-galactose and $\mathrm{N}$ acetyl D-glucosamine in the molar ratios $0 \cdot 46: 0 \cdot 35: 1 \cdot 57: 1 \cdot 0$. No $N$-acetylneuraminic acid was detected. 


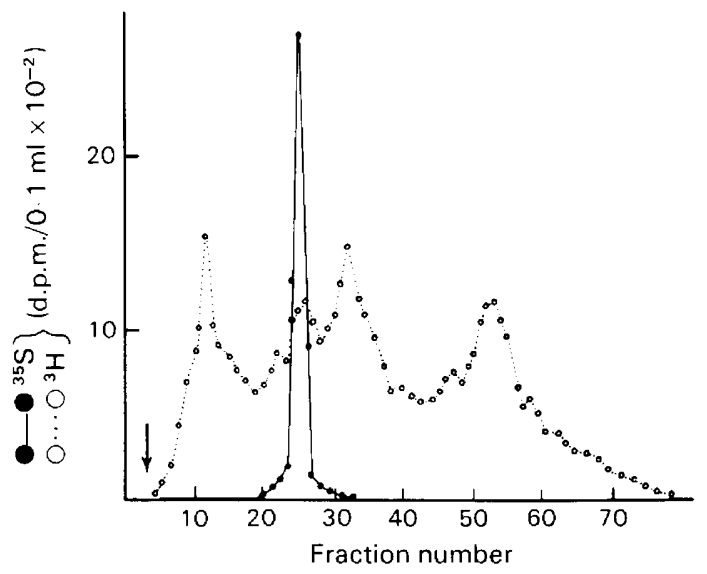

Text-fig. 7. DEAE-cellulose ion exchange chromatograph of medium from incubation of 2 blastocysts, from a single ewe at Day-16 of pregnancy, with $200 \mu \mathrm{Ci}{ }^{35} \mathrm{SO}_{4}$ and $100 \mu \mathrm{Ci} \mathrm{L}$ $\left[{ }^{3} \mathrm{H}\right]$ leucine for $24 \mathrm{~h}$. The arrow shows the start of the gradient; $0.1 \mathrm{ml}$ samples of each fraction of the eluate were analysed. The high molecular weight glycoprotein eluted between fractions 10 and 15 .

\section{Labelling with ${ }^{35} \mathrm{SO}_{4}$}

Day 16 sheep conceptuses were cultured in the presence of $\mathrm{L}-\left[{ }^{3} \mathrm{H}\right]$ leucine $(100 \mu \mathrm{Ci})$ and ${ }^{35} \mathrm{SO}_{4}$ $(100 \mu \mathrm{Ci})$ for $24 \mathrm{~h}$. The dialysed medium was then subjected to DEAE-ion exchange chromatography. The initial glycoprotein peak did not contain any ${ }^{35} \mathrm{~S}$. However, a sharp peak of ${ }^{35} \mathrm{~S}$ radioactivity was eluted about one-third of the way through the salt gradient (Text-fig. 7), suggesting that at least one of the products produced by the blastocyst was sulphated. No late eluting peaks of ${ }^{35} \mathrm{~S}$ were detected; nor was any ${ }^{35} \mathrm{~S}$ eluted by washing the column with $1.5 \mathrm{M}-\mathrm{NaCl}$ after the initial gradient. These results are consistent with the view that the blastocyst does not secrete sulphated proteoglycans.

\section{Treatment of pronase glycopeptides with $\beta$-endogalactosidase}

The glycopeptides eluting between fractions 20 and 30 during Sephacryl S-200 chromatography of pronase-digested glycoprotein (see Text-fig. 6a) were concentrated and digested with endo- $\beta$ galactosidase at pH $6.0\left(48 \mathrm{~h} ; 37^{\circ} \mathrm{C}\right)$. The extent of hydrolysis by this enzyme is used as a test for internal $\beta$-galactosidic linkages on linear, unbranched chains lacking substituted galactosyl units (see $\mathrm{Li}$, Gibson \& Kornfeld, 1980). Only $16 \%$ of the $\left[{ }^{3} \mathrm{H}\right]$ glucosamine was released as low molecular weight compounds; no $\left[{ }^{14} \mathrm{C}\right]$ leucine label was released.

\section{Discussion}

These experiments show that the major glucosamine-labelled product released by sheep, pig and cow blastocysts during the period of rapid elongation is a glycoprotein of high molecular weight. It was released in a continuous linear fashion throughout a $24 \mathrm{~h}$ culture period and up to $50 \mu \mathrm{g}$ could be purified from a single sheep conceptus incubation. The yield from the pig blastocyst (unpublished results) was much less.

In each of the species, the glycoprotein consisted of at least $50 \%$ carbohydrate. The size of the oligosaccharide chains has not been determined accurately since pronase digestion released only 
about half of the polypeptide, as determined by loss of $\mathrm{L}-\left[{ }^{14} \mathrm{C}\right]$ leucine. It seems likely that large segments of the molecule may be relatively resistant to proteolysis, as has been found with some mucins, in which large numbers of carbohydrate chains are packed close together on relatively short segments of polypeptide (see Horowitz, 1977; Pigman, 1977).

Although we have been unable to purify sufficient material to analyse the pig and cow material in detail, it is evident that the sheep glycoprotein is not of the usual mucin type because (a) it appears to lack significant quantities of the amino sugar $\mathrm{N}$-acetyl-D-galactosamine which is the linkage sugar between the oligosaccharide chain and threonine and/or serine residues on the polypeptide portion of mucin; (b) preliminary amino acid analyses did not indicate an unusually high content of hydroxylated amino acids (unpublished results); (c) it lacks sialic acid which typically terminates the oligosaccharide chains of many mucins; and (d) it contains mannose and $\mathrm{N}$-acetylglucosamine which are normal components of asparagine-linked oligosaccharide chains, but uncommon in most well characterized mucins (Kornfeld \& Kornfeld, 1976). The results with alkaline borohydride on all three species of glycoprotein were equivocal, however. This treatment cleaves $O$-linked chains completely from the polypeptide portion of the molecule by a transelimination reaction, but leaves $N$-linked oligosaccharides intact (Zinn et al., 1977). In all three species considerable cleavage of the molecule did occur, but the procedure failed to release carbohydrate from the labelled amino acid (i.e. the two probably remained covalently linked). The most likely explanation is that the glycoprotein possesses a number of peptide linkages susceptible to hydrolysis with $0 \cdot 1 \mathrm{M}$-alkali. Because considerable differences in peptide bond sensitivity to hydrolysis are known to occur in proteins, such cleavages are perhaps not unexpected.

The molecule is also clearly not a proteoglycan. Its early elution from the anion exchange column, lack of uronic acid content and failure to incorporate ${ }^{35} \mathrm{SO}_{4}$ rule out such a possibility. Indeed, none of the blastocyst species appeared to produce any sulphated proteoglycans or any hyaluronic acid. The latter would be labelled with glucosamine, and elute towards the end of the linear salt gradient (Welch \& Roberts, 1975).

Our results indicate that approximately half of the mass of the sheep glycoprotein is carbohydrate, and that the main sugars are $N$-acetylglucosamine and galactose. The presence of mannose suggests that the glycoprotein may possess the common internal 'core' found on asparagine-linked oligosaccharides (Kornfeld \& Kornfeld, 1976). There have been several reports of carbohydrate chains on complex saccharides with a sugar composition resembling that reported here (Järnefelt, Rush, Li \& Laine, 1978; Fukuda, Fukuda \& Hakamori, 1979; Watanabe, Hakamori, Childs \& Feizi, 1979; Li et al., 1980). In general, the molecules are polymers with various degrees of branching and composed primarily of linear, repeating regions of [galactosyl-( $\beta 1 \rightarrow 4) 2$-deoxy-2acetamidoglucosyl $(\beta 1 \rightarrow 3)$ ] units. Of particular interest to our study is the report of similar glycoproteins being present on the surface of embryonal carcinoma cells (Muramatsu et al., 1978; Muramatsu, Gachelin, Damonneville, Delabre \& Jacob, 1979a; Muramatsu, Gachelin \& Jacob, $1979 \mathrm{~b}$ ). The glycopeptides on these molecules also possessed a ratio of galactose to glucosamine of approximately $2: 1$ and were relatively resistant to the action of Erwinia freundii endo- $\beta$-galactosidase (Muramatsu et al., 1979a), suggesting that they were extensively branched.

The function of the glycoprotein in relation to pregnancy is unknown. It is clearly a major product of the cow, pig and sheep blastocyst. Its appearance in the medium could possibly be an artefact of in-vitro culture, and the molecule may not normally be released in soluble form but, instead, may be deposited between cells or on the trophoblast surface. In the mouse, glycoproteins bearing carbohydrate chains of similar composition have been implicated in the process of compaction by cleavage-stage embryos (Hyafil, Morello, Babinet \& Jacob, 1980). However, in the sheep, the glycoprotein does not appear to be produced until during the period of rapid blastocyst elongation (Godkin et al., 1982). Similar observations have recently been made with the pig (W. G. Gray \& R. M. Roberts, unpublished results). Thus, the glycoprotein may be involved in providing a protease-resistant or immunologically tolerant coating over the blastocyst surface as it expands. Alternatively, it may be a blastocyst product necessary for controlling cell movement and cell-cell 
interactions during the dramatic sphere to filament transformation, which is characteristic of the blastocysts of all three of these species (see Bindon, 1971; Anderson, 1978; Wathes \& Wooding, $1980)$.

The research was supported by grant HD10346 from the National Institutes of Health and U.S. Department of Agriculture, Cooperative State Research Agreement No. 616-15-162. We thank Dr Y.-T. Li for the gift of endo- $\beta$-galactosidase and Catherine Willis, Frank Bartol, Jeff Moffatt and Rod Geisert for assistance with the surgery.

\section{References}

Aminoff, D. (1961) Methods for the quantitative estimation of $N$-acetylneuraminic acid and their application to hydrolyzates of sialomucoids. Biochem. J. 81, 384392.

Anderson, L.L. (1978) Growth, protein content and distribution of early pig embryos. Anat. Rec. 190, 143154.

Basha, S.M.M., Bazer, F.W. \& Roberts, R.M. (1979) The secretion of a uterine specific, purple phosphatase by cultured explants of porcine endometrium. Dependency upon the state of pregnancy of the donor animal. Biol. Reprod. 20, 431-441.

Bazer, F.W., Chen, T.T., Knight, J.W., Schlosnagle, D., Baldwin, N.J. \& Roberts, R.M. (1975) Presence of a progesterone-induced, uterine specific, acid phosphatase in allantoic fluid of gilts. J. Anim. Sci. 41, 1376-1382.

Bazer, F.W., Sharp, D.C. \& Roberts, R.M. (1978) Collection and analysis of female genital tract secretions. In Methods in Mammalian Embryology, pp. 503-528. Ed. J. C. Daniel, Jr. Academic Press, New York.

Bazer, F.W., Roberts, R.M., Sharp, D.C. \& Thatcher, W.W. (1981) Uterine proteins synthesized during the progestative period and pregnancy. In Utérus et Fécondité, pp. 17-32. Eds C. Boury-Heyler, P. Mauléon \& Y. Rochet. Masson, Paris.

Bertolini, M. \& Pigman, W. (1967) Action of alkali on bovine and ovine submaxillary mucins. J. biol. Chem. 242, 3776-3781.

Bindon, B.M. (1971) Systematic study of preimplantation stages of pregnancy in the sheep. Aust. J. biol. Sci. 24, $131-147$.

Bitter, T. \& Muir, H.M. (1962) A modified uronic acid carbazole reaction. Analyt. Biochem. 4, 330-334.

Boshier, D.P. (1969) A histological and histochemical examination of implantation and early placentome formation in sheep. $J$. Reprod. Fert. 19, 51-61.

Clamp, J.R., Bhatti, T. \& Chambers, R.E. (1971) The determination of carbohydrate in biological materials by gas liquid chromatography. In Methods of Biochemical Analysis, Vol. 19, pp. 229-344. Ed. D. Glick. John Wiley \& Sons, Inc., New York.

Crombie, P. (1972) Ultrastructure of the pig's placenta throughout pregnancy. Ph.D. thesis, University of Cambridge.

Davidson, E.A. (1965) Metabolism of amino sugars. In The Amino Sugars, Vol. IIB, pp. 1-44. Eds E. A. Balazs \& R. G. Jeanloz. Academic Press, New York.

Dubois, M., Gilles, K.A., Hamilton, J.K., Riebers, P.A. \& Smith, F. (1956) Colorimetric method for determina- tion of sugars and related substances. Analyt. Chem. 28, 350-356

Friess, A.E., Sinowatz, F., Skolek-Winnisch, R. \& Trautner, W. (1980) The placenta of the pig. Fine structural changes of the placental barrier during pregnancy. Anat. Embryol. 158, 179-191.

Fukuda, M., Fukuda, M.N. \& Hakamori, S. (1979) Developmental change and genetic defect in the carbohydrate structure of band 3 glycoprotein of human erythrocyte membrane. J. biol. Chem. 254, 37003703.

Godkin, J.D., Bazer, F.W., Mofiatt, J., Sessions, F. \& Roberts, R.M. (1982) Purification and properties of a low molecular weight protein released by the trophoblast of sheep blastocysts at Day 13-21.J. Reprod. Fert. 65, 141-150.

Horowitz, M.I. (1977) Gastrointestinal glycoproteins. In The Glycoconjugates, Vol. I, pp. 189-213. Eds M. I. Horowitz \& W. Pigman. Academic Press, New York.

Hyafil, F., Morello, D., Babinet, C. \& Jacob, F. (1980) A cell surface glycoprotein involved in the compaction of embryonal carcinoma cells and cleavage stage embryos. Cell 21, 927-934.

Järnefelt, J., Rush, J., Li, Y.-T. \& Laine, R. (1978) Erythroglycan, a high molecular weight glycopeptide with the repeating structure [galactosyl $(1 \rightarrow 4) 2$-deoxy-2acetamidoglucosyl $(1 \rightarrow 3)$ ] comprising more than onethird of the protein-bound carbohydrate of human erythrocytes. J. biol. Chem. 253, 8006-8009.

King, G.J., Atkinson, B.A. \& Robertson, H.A. (1980) Development of the bovine placentome from Days 20 to 29 of gestation. J. Reprod. Fert. 59, 95-100.

Klopper, A. (1980) The new placental proteins. Placenta 1, 77-89.

Kohn, P., Winzler, R.J. \& Hoffmann, R.C. (1962) Metabolism of D-glucosamine in the intact rat. J. biol. Chem. 237, 304-308.

Kornfeld, R. \& Kornfeld, S. (1976) Comparative aspects of glycoprotein structure. Analyt. Biochem. 45, 217237.

Kozulic, B., Ries, B. \& Mildner, P. (1979) N-Acetylation of amino sugars methylglycosides for gas-liquid chromatographic analysis. Analyt. Biochem. 94, 36-39.

Li, E., Gibson, R. \& Komfeld, S. (1980) Structure of an unusual, complex-type oligosaccharide isolated from Chinese hamster ovary cells. Archs Biochem. Biophys. 199, 393-399.

Lowry, O.H., Rosebrough, N.J., Farr, A.L. \& Randall, A.J. (1951) Protein measurement with the Folin phenol reagent. J. biol. Chem. 193, 265-275. 
Moor, R.M. \& Rowson, L.E.A. (1964) Influence of the embryo and uterus on luteal function in the sheep. Nature, Lond. 201, 522-523.

Muramatsu, T., Gachelin, G., Nicolas, J.F., Condamine, H., Jakob, H. \& Jacob, F. (1978) Carbohydrate structure and cell differentiation: unique properties of fucosyl-glycopeptides isolated from embryonal carcinoma cells. Proc. natn. Acad. Sci. U.S.A. 75, 2315-2319.

Muramatsu, T., Gachelin, G., Damonneville, M., Delabre, C. \& Jacob, F. (1979a) Cell surface carbohydrates of embryonal carcinoma cells: polysaccharide side chains of $F 9$ antigens and of receptors to two lectins, FBP and PNA. Cell 18, 183-191.

Muramatsu, T., Gachelin, G. \& Jacob, F. (1979b) Characterization of glycopeptides isolated from membranes of F9 embryonal carcinoma cells. Biochim. Biophys. Acta 587, 392-406.

Perry, J.S. (1981) The mammalian fetal membranes. $J$. Reprod. Fert. 62, 321-335.

Pigman, W. (1977) Mucus glycoproteins: introduction. In The Glycoconjugates, Vol. 1, pp. 131-135. Eds M. I. Horowitz \& W. Pigman. Academic Press, New York.

Porter, D.G. (1980) Feto-maternal relationships: the actions and control of certain placental hormones. Placenta 1, 259-274.

Rondle, C.J.M. \& Morgan, W.T.J. (1955) The determination of glucosamine and galactosamine. Biochem.

\section{J. 61, 586-589.}

Spiro, R.G. (1972) Study of the carbohydrates of glycoproteins. In Methods in Enzymology, Vol. 28, pp. 3536. Ed. V. Ginsburg. Academic Press, New York.

Steven, D. (1975) Anatomy of the placental barrier. In Comparative Placentation, pp. 25-57. Ed. D. H. Steven. Academic Press, London.

Warren, L. (1959) The thiobarbituric acid assay of sialic acids. J. biol. Chem. 234, 1971-1975.

Watanabe, K., Hakamori, S., Childs, R.A. \& Feizi, T. (1979) Characterization of a blood group I-active ganglioside: structural requirements for I and i specificities. J. biol. Chem. 254, 3221-3228.

Wathes, D.C. \& Wooding, F.B.P. (1980) An electron microscopic study of implantation in the cow. Am. J. Anat. 159, 285-306.

Welch, D.W. \& Roberts, R.M. (1975) Complex saccharide metabolism in cystic fibrosis fibroblasts. Pediat. Res. 9, 698-702.

Zinn, A.B., Plantner, J.J. \& Carison, D.M. (1977) Nature of linkages between protein core and oligosaccharides. In The Glycoconjugates, Vol. I. pp. 69-85. Eds M. I. Horowitz \& W. Pigman. Academic Press, New York.

Received 18 February 1982 